Original article

\title{
Structure of the artificial hard substrate assemblages in ports in Thermaikos Gulf (North Aegean Sea)
}

\section{Assemblages de substrats durs artificiels dans des ports du nord de la mer Égée (golfe de Thermaikos)}

\author{
Panagiotis Karalis, Chryssanthi Antoniadou, Chariton Chintiroglou * \\ Department of Zoology, School of Biology, Aristotle University, PO Box 134, 54006 Thessaloniki, Greece
}

Received 7 November 2002; revised and accepted 27 February 2003

\begin{abstract}
The present study describes the hard substrate assemblages established on the concrete blocks of three ports placed in gradually longer distances from the main source of pollution in Thermaikos Gulf. The samplings were performed on a seasonal basis for a 2-year period. The data analysis indicates a clear separation of the assemblages from each port. Evenness and Shannon-Weaver diversity indices were calculated and their values were found to be quite high. This fact, combined with the seasonal pattern that these assemblages hold, reveals stability and a good adaptation of their faunistic components to local environmental conditions. A change due to the construction of a new block functioning as a surge barrier was detectable at the station of N. Michaniona. Once again, biomonitoring proves to be essential in order to obtain useful information about the water conditions. Emphasis was laid on the taxa of Polychaeta by analyzing their numerical abundance and their feeding guilds separately. The results were very similar, a fact that supports the opinion that a specific taxonomic group can be used for the description and the monitoring in many different cases.
\end{abstract}

(C) 2003 Éditions scientifiques et médicales Elsevier SAS and Ifremer/CNRS/IRD. All rights reserved.

\section{Résumé}

Ce travail décrit les assemblages de substrats durs qui se sont établis sur des blocs dans trois ports de plus en plus éloignés des sources de pollution dans le golfe de Thermaikos. Des prélèvements saisonniers durant deux années montrent une séparation nette des assemblages des trois ports. Les indices de diversité (Shannon-Weaver) et d'équitabilité sont plutôt élevés. Ce fait, ainsi que le schéma saisonnier, révèlent une stabilité et une bonne adaptation de la faune à son environnement. Un changement dû à la construction d'un nouveau bloc établi pour barrer la houle est détectable à la station du port N Michaniona. Une fois de plus, le suivi biologique paraît essentiel pour obtenir des informations utiles sur les conditions environnementales. L'accent est mis sur les taxons de polychètes en mesurant l'abondance des différentes guildes trophiques. Les résultats sont voisins, ce qui prouverait qu'un groupe taxinomique spécifique peut être utilisé pour décrire et suivre l'évolution dans pas mal de cas.

(C) 2003 Éditions scientifiques et médicales Elsevier SAS and Ifremer/CNRS/IRD. All rights reserved.

\footnotetext{
* Corresponding author.

E-mail address: chintigl@ bio.auth.gr (C. Chintiroglou).
} 


\section{Introduction}

The research for the assessment of sea pollution has troubled the scientific society worldwide. It is generally true that when the numerical abundance is high, diversity is low. According to Bellan-Santini et al. (1994), this is more obvious for oligotrophic systems like the Mediterranean Sea, where in normal conditions we observe low abundance and high diversity. It is also acceptable that when an assemblage shows variations of its normal faunal composition or loses its seasonal pattern, a kind of disturbance in the area has probably occurred (Gray and Mirza, 1979).

Studies on marine benthic ecology have proved to be extremely useful tools, since they provide data applicable for biomonitoring. During the last 60 years, numerous research programs were dedicated to the collection of data concerning the Mediterranean benthic assemblages, as the existing bibliographic references prove. This attempt mostly concerns the soft substrate assemblages, mainly due to the easiest application of soft substrate sampling techniques. The majority of the existing data on hard substrate assemblages derives from studies in Marseille and Italy (Pérès and Picard, 1964; Bellan-Santini, 1968, 1981; Bellan-Santini et al., 1976, 1994; Tack Kit, 1976; Bellan, 1980; Bitar, 1982; Desrosiers et al., 1986 and others). Furthermore, information relating to both structure and function of the artificial hard substrate assemblages in ports is very limited (Hargrave and Thiel, 1983; Bellan and Pérès, 1994; Baxevanis and Chintiroglou, 2000).

Many authors point out that the structure of benthic assemblages reflects the integrated conditions over a period of time. Consequently this kind of data is extremely helpful for pollution impact studies due to anthropogenic interference. In order to be able to identify such cases, as forced by many international directives and conventions, it is necessary to create a database concerning the composition of natural assemblages (Gaston and Spicer, 1996).

The aim of this study is to give for the first time the results on the structure and organization (terms as given from Desrosiers et al., 1986) of hard substrate assemblages in three ports (with mainly different operation) of Thermaikos Gulf (North Aegean Sea), in order to (a) register the benthic invertebrate fauna in space and time, (b) evaluate the effect of pollution on the structure of these assemblages and (c) assess the environmental impact of technical port constructions in the wider geographical area.

\section{Materials and methods}

\subsection{Description of sampling stations}

The choice of sampling stations was based on three criteria: (1) their distance from the main source of pollution which is located at the northwest side of the gulf, (2) their homogeneity in terms of substrate and time of construction (concrete blocks, more than 15 years in order to obtain

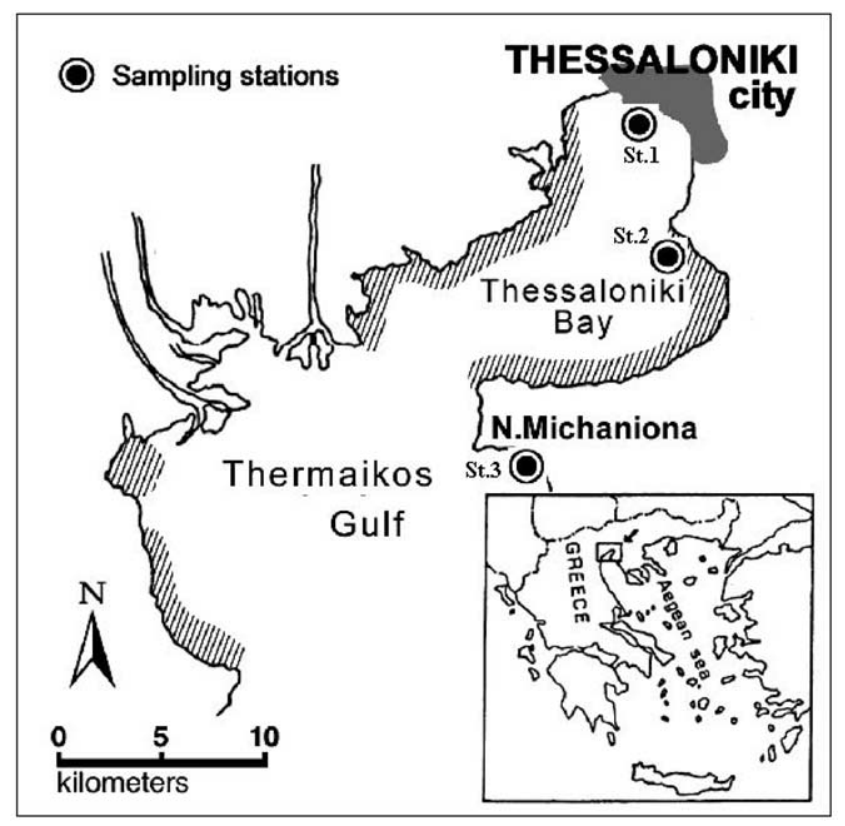

Fig. 1. Map of the three sampling stations where St.1 shows the main port of Thessaloniki, St.2, the marina of Kalamaria and St.3, the fishery port in N. Mihaniona.

assemblages in a late stage of the colonization process), and (3) their differences concerning the degree and kind of pollution.

\subsection{Station 1: main port of Thessaloniki}

The main port of Thessaloniki is located at the northwestern side of the bay (Fig. 1), thus the closest to the main pollution sources. It is the second biggest port in Greece and harbors a great number of commercial and passenger boats every day. It is under the influence of sewage produced by the neighboring industrial area of Thessaloniki, but it also receives the majority of city's urban sewage. The mean depth reaches $10 \mathrm{~m}$ and is strongly exposed to southern winds, resulting in a satisfactory water renewal.

\subsection{Station 2: marina of Kalamaria}

The marina of Kalamaria is located at the northeastern side of the city Fig. 1. Its relatively small size restricts its function to harboring only a small number of littoral fishing boats and yachts anchors there. The marina receives urban sewage from the area of Kalamaria and it is additionally affected by toxic materials coming from the painting of tourist yachts. Two important factors in this site are the small depth (mean depth at about $2 \mathrm{~m}$, maximum at $4 \mathrm{~m}$ ) and protection from the wave action due to a storm-surge barrier in parallel with the shore, creating an artificial wall and, thus, obstructing water renewal.

\subsection{Station 3: port of N. Michaniona}

This station is located at the northeastern side of Thermaikos Gulf, $30 \mathrm{~km}$ away from the city of Thessaloniki Fig. 1. 
Consequently it is far away from industrial and the majority of urban sewage, receiving only local rejects. It serves mainly the fisheries, containing a great number and variety of boats. Almost the entire fishing fleet of Thermaikos Gulf anchors there. Besides the fishery boats waste, this station receives organic material from the estuaries system of Axios Loudias and Aliakmonas rivers located at the northwestern side of the gulf. We must also add the fact that the port is strongly exposed to the north winds. So, in combination with its depth (mean depth around $6 \mathrm{~m}$ ), we can suggest that water renewal is satisfactory.

\subsection{Physico-chemical factors}

During this study, the main abiotic factors $(\mathrm{pH}$, temperature, salinity, conductivity, dissolved oxygen, total hydrodynamism and water clarity) were measured at each sampling site on a monthly basis. All measurements were made with a WTW salinity-conductivity- $\mathrm{O}_{2}$ meter and Lovibond Checkit (pH-meter) micro-electronic equipment. The water clarity was determined using the Secchi disc. The evaluation of total hydro-dynamism was based on the corrosion of plaster into the water (Kaandorp, 1986).

\subsection{Classification of the Polychaetes' feeding guilds}

Overall 57 species of Polychaetes were identified in our samples and classified in 10 feeding guilds, based on the models proposed by Fauchald and Jumars (1979). These guilds were: BMJ, BMX, BSX, CMJ, CDJ, HMJ, SMT, SDT, SST, FST, where B stands for burrowers, C carnivores, H herbivores, $\mathrm{S}$ surface deposit-feeders, F Filter-feeders, M motile, middle $\mathrm{S}$ sessile, D discretely motile, J jawed pharynx, X unarmed pharynx and T tentaculate. The basic criteria for this classification are the quantity, the kind of food and the activity they show while consuming their food (Damianidis and Chintiroglou, 2000).

\subsection{Data collection-statistical analysis}

All samples were collected from the cement piers of each port facility, which were constructed over 15 years ago. The depth of the sampling efforts responded to the average depth of the underwater cement columns of the piers (4 $\mathrm{m}$ in st1, $2 \mathrm{~m}$ in st 2 and $3 \mathrm{~m}$ in st 3 ). Samplings were carried out by scuba diving using a modified quadrate sampler of $400 \mathrm{~cm}^{2}$, which is the minimum necessary surface for a statistically sound investigation on hard substrate (Weinberg, 1978; Stirn, 1981; Chintiroglou and Koukouras, 1992). According to Bakus (1990), three replicates per station were collected from the same diver (third author) at each period, preserved in a $10 \%$ formalin solution and transferred to the laboratory for further investigation. Overall samples were available for winter 1994, summer 1994, winter 1995 and summer 1995. During samplings, the physiognomic aspect of the biotops was recorded with an underwater camera in order to obtain data concerning the megafauna component of the biota. All organisms were counted and identified at species level. Common biocoenotic methods were employed to analyze the data (Guille, 1970 and others). The numerical abundance was estimated on a scale of $1 \mathrm{~m}^{2}$. The estimation of frequency was annual. Shannon $\left(H^{\prime}\right)$ and Evenness $\left(J^{\prime}\right)$ indices were also calculated. The numerical abundance per sampling period was analyzed using cluster and multidimensional scaling techniques (MDS), based on the Bray-Curtis similarity and log transformed numerical abundances, with Primer package (see Clarke and Warwick, 1994). The significance of the multivariate results was assessed using Anosim test. Furthermore the taxa of polychaeta were analyzed separately in more details using the numerical abundance of (a) species composition and (b) feeding guilds in order to perform a cluster and MDS analysis based on the same principles as mentioned above.

\section{Results-Discussion}

\subsection{Abiotic factors}

Hydro-dynamism was measured by checking the corrosion of plaster at each station: st $1=32.25 \%$, st $2=19.60 \%$ and st $3=50.79 \%$, so the stations can be ranked as follows: st3 $>$ st $1>$ st 2 . Dissolved $\mathrm{O}_{2}$ showed no significant fluctuations in time at all stations, as its values ranged between 6.5 and $8 \mathrm{ppm}$. The only exception was at st 2 , where, as a result of minor renewal and high temperatures during summertime, the values ranged at a lower level (4-5 ppm). The $\mathrm{pH}$ values were almost constant to 8 at all stations. Regarding the other abiotic factors, the measured values produced a more or less seasonal pattern. Temperature ranges seasonally from 10.9 to $28.7^{\circ} \mathrm{C}$. The pattern of salinity $\left(35.8-37.9^{\circ} \mathrm{C}\right)$ and conductivity $\left(49.0-52.1 \mu \mathrm{s} \mathrm{cm}^{-1}\right)$ ranges in a similar way, with the lowest values occurring during summer months. This fact is illustrated by many authors and is due to the influence of the estuary systems and the occurrence of south, southeast winds. As a result, freshwater masses are transferred to the inner part of the bay (Krestenitis et al., 1997; Kamba et al., 2000).

\subsection{Classification and description of the assemblages}

At that part of the analysis, the meiofauna including the taxonomic group of Nematoda and Copepoda was excluded.

At the first station, the main port of Thessaloniki, a total of 70 species was recorded. In accordance with their frequency $(F), 37$ of them were named as characteristic, 28 as common and five as rare Tables 1 and 4 . In regards to the mean dominance of the characteristic species as a total, it looks that they cover the $84 \%$ of the total abundance. The most representative of the characteristic species were Stylochus sp., Hydroides norvegica, Ophiodromus pallidus, Staurocephalus rudolphii, Corophium acutum, Elasmopus rapax, Erichthonius brasiliensis, Clavelina lepatiformis and Styella partita. Their mean dominance ranges from $4.54 \%$ to 
Table 1

Mean numerical abundance $(\mathrm{mA})$, frequency $(F)$ and mean dominance $(\mathrm{mD})$ values from the main port of Thessaloniki (st1)

\begin{tabular}{|c|c|c|c|c|c|c|c|c|c|}
\hline Taxa & st1 w94 & st1 s94 & $F(\%)$ & st1 w95 & st1 s95 & $F(\%)$ & $\mathrm{mA}$ & $\mathrm{mD}$ & $F(\%)$ \\
\hline Eudendrium sp. & $*$ & $*$ & 100 & $*$ & $*$ & 100 & $*$ & $*$ & 100 \\
\hline Stylochus sp. & 58 & 410 & 100 & 85 & 159 & 100 & 59.33 & 4.553 & 100 \\
\hline Nematoda & 122 & 2077 & 83 & 14 & 51 & 66 & 188.7 & 14.48 & 75 \\
\hline Dodecaceria concharum & 4 & 11 & 83 & 7 & 4 & 83 & 2.16 & 0.166 & 83 \\
\hline Harmothoe spinifera & 107 & 8 & 100 & 21 & 26 & 100 & 13.5 & 1.036 & 100 \\
\hline H. norvegica & 152 & 517 & 100 & 3 & 39 & 83 & 59.25 & 4.547 & 92 \\
\hline Hydroides pseudouncinata & 39 & 31 & 100 & 21 & 74 & 100 & 13.75 & 1.055 & 100 \\
\hline Magalia perarmata & 13 & 3 & 66 & 17 & 5 & 83 & 3.17 & 0.243 & 75 \\
\hline Nereis succinea & 8 & 24 & 100 & 3 & 17 & 50 & 4.33 & 0.332 & 75 \\
\hline O.pallidus & 42 & 499 & 100 & 313 & 794 & 100 & 137.3 & 10.54 & 100 \\
\hline P. dumerilii & & 11 & 16 & 5 & 20 & 100 & 3 & 0.23 & 58 \\
\hline Polydora caeca & 22 & 7 & 83 & 4 & 9 & 66 & 3.5 & 0.269 & 75 \\
\hline Prionospio steenstrupi & 17 & 104 & 83 & 21 & 40 & 100 & 15.17 & 1.164 & 92 \\
\hline Sabellaria spinulosa & 2 & 32 & 83 & 10 & 10 & 100 & 4.5 & 0.345 & 92 \\
\hline S. rudolphii & 314 & 195 & 100 & 198 & 158 & 100 & 72.08 & 5.532 & 100 \\
\hline Terebella lapidaria & 55 & 120 & 100 & 29 & 51 & 100 & 21.25 & 1.631 & 100 \\
\hline Vermiliopsis infundibulum & & 30 & 50 & 5 & 14 & 83 & 4.08 & 0.313 & 67 \\
\hline Arca noae & 2 & 7 & 66 & 1 & 3 & 50 & 1.08 & 0.083 & 58 \\
\hline Gregaciella sulcata & 6 & 16 & 83 & & 3 & 33 & 2.08 & 0.16 & 58 \\
\hline Turboella lia & 2 & 7 & 66 & 9 & 1 & 50 & 1.58 & 0.121 & 58 \\
\hline Callipalene sp. & 11 & 121 & 100 & 6 & 51 & 100 & 15.75 & 1.209 & 100 \\
\hline L. savignyi & 7 & & 50 & 8 & 4 & 100 & 1.58 & 0.121 & 75 \\
\hline Cymodoce tuberculata & 10 & 21 & 100 & 171 & 43 & 100 & 21.25 & 1.631 & 100 \\
\hline C. acutum & 10 & 317 & 83 & 46 & 366 & 100 & 61.58 & 4.726 & 92 \\
\hline E. rapax & 4 & 355 & 100 & 439 & 1019 & 100 & 151.4 & 11.62 & 100 \\
\hline L. savignyi & & 539 & 50 & 69 & 161 & 100 & 64.08 & 4.918 & 85 \\
\hline Pachygrapsus marmoratus & 28 & 233 & 100 & 44 & 98 & 100 & 33.58 & 2.577 & 100 \\
\hline Pisidia longicornis & 67 & 39 & 100 & 26 & 29 & 83 & 13.42 & 1.03 & 92 \\
\hline Bowerbankia sp. & $*$ & $*$ & 100 & $*$ & $*$ & 100 & $*$ & $*$ & 100 \\
\hline B. stolonifera & & $*$ & 33 & $*$ & $*$ & 100 & $*$ & $*$ & 67 \\
\hline Bryozoa sp.1 & & $*$ & 50 & $*$ & $*$ & 66 & $*$ & $*$ & 58 \\
\hline C. intestinalis & 18 & 5 & 50 & 124 & 2 & 83 & 12.42 & 0.953 & 67 \\
\hline Clavelina lepadiformis & 1063 & & 50 & 121 & & 50 & 98.67 & 7.573 & 50 \\
\hline Pyura microcosmus & 3 & 5 & 100 & 3 & 11 & 83 & 1.83 & 0.14 & 92 \\
\hline S. partita & 9 & 722 & 83 & 172 & 906 & 100 & 150.8 & 11.57 & 92 \\
\hline Styella plicata & 2 & 8 & 66 & 1 & 68 & 66 & 6.58 & 0.505 & 66 \\
\hline
\end{tabular}

$11.62 \%$. It should be noted that the ascidian Ciona intestinalis and the three Bryozoan species, whose numerical abundances were relatively low, are very frequent in our samples. This fact is attributed mainly to the sampling surface of the quadrate sampler used for the purposes of this research, which concerns mostly the macrofauna species. In order to cover the distribution of some megafauna species as those above, a surface from $0.5 \times 0.5$ to $1 \times 1 \mathrm{~m}^{2}$, in dependence with the size of the target species, would be more preferable (Stirn, 1981).

At the marina of Kalamaria (st2), 74 species were recorded. Overall 41 were classified as characteristic with a total mean dominance that exceeded $99 \%$ Tables 2 and 4 . The most dominant species were $H$. norvegica, Serpula vermicularis, Leptochelia savignyi, C. acutum, E. rapax, E. brasiliensis, $C$. lepatiformis and $S$. partita (mean dominance ranging from $2.4 \%$ to $29.81 \%$ ). The presence of $C$. intestinalis was low, when compared with st1.

At the fishery port of N. Michaniona, 108 species were found, 41 of which were characteristic (total mean dominance over 97\%) as Tables 3 and 4 show. From these species, Aiptasiogeton pellucidus, Exogone gemmifera, Scoletoma funchalensis, L. savignyi, C. acutum, Corophium sextonae, E. rapax, E. brasiliensis and Balanus eburneus contribute the most to the total abundance (mean dominance ranging from $1.5 \%$ to $29.8 \%$ ).

Besides the differences observed at the three stations, it is generally true that the taxonomic group of Polychaeta prevails in all the examined port assemblages, with a percentage ranging from $41 \%$ to $50 \%$. Next follow the Crustacea (20$24 \%$ ) and the Mollusca (10\%). These results, presented in Table 4 are in accordance with relevant studies in the 
Table 2

Mean numerical abundance $(\mathrm{mA})$, frequency $(F)$ and mean dominance $(\mathrm{mD})$ values from Kalamaria harbor $(\mathrm{st} 2)$

\begin{tabular}{|c|c|c|c|c|c|c|c|c|c|}
\hline Taxa & st2 w94 & st2 s94 & $F(\%)$ & st2 w95 & st2 s95 & $F(\%)$ & $\mathrm{mA}$ & $\mathrm{mD}$ & $F(\%)$ \\
\hline Cliona sp. & $*$ & * & 66 & $*$ & $*$ & 83 & $*$ & $*$ & 75 \\
\hline Eudendrium sp. & & * & 16 & $*$ & $*$ & 83 & $*$ & $*$ & 50 \\
\hline A. pellucidus & 99 & 199 & 100 & 37 & 499 & 100 & 69.5 & 1.966 & 100 \\
\hline Stylochus sp. & 18 & 47 & 100 & 30 & 602 & 100 & 58.08 & 1.643 & 100 \\
\hline Nematoda & 35 & 53 & 100 & 24 & 9 & 66 & 10.08 & 0.285 & 83 \\
\hline Oligochaeta & 6 & 11 & 66 & 6 & 15 & 66 & 3.17 & 0.09 & 67 \\
\hline E. gemmifera & 38 & 63 & 100 & 93 & 54 & 100 & 20.67 & 0.585 & 100 \\
\hline H. spinifera & 2 & 2 & 50 & 4 & 1 & 50 & 0.75 & 0.021 & 50 \\
\hline Heterocirrus alatus & 21 & 13 & 100 & 37 & 13 & 100 & 7 & 0.198 & 100 \\
\hline Heterocirrus bioculatus & 148 & 32 & 83 & 70 & 67 & 100 & 26.42 & 0.747 & 92 \\
\hline Heteromastus filiformis & 24 & 39 & 83 & 110 & 17 & 100 & 15.83 & 0.448 & 92 \\
\hline H. norvegica & 40 & 122 & 100 & 133 & 1170 & 100 & 122.08 & 3.453 & 100 \\
\hline H. pseudouncinata & 69 & 65 & 100 & 44 & 43 & 100 & 18.42 & 0.521 & 100 \\
\hline N. succinea & 1 & 20 & 66 & & 2 & 33 & 0.25 & 0.007 & 50 \\
\hline O.pallidus & 1 & 10 & 50 & 25 & 31 & 100 & 5.58 & 0.158 & 75 \\
\hline Phyllodoce madeirensis & 4 & 2 & 83 & 4 & 9 & 100 & 1.58 & 0.045 & 92 \\
\hline P. caeca & 63 & 28 & 100 & 43 & 15 & 100 & 12.42 & 0.351 & 100 \\
\hline P. steenstrupi & 28 & 42 & 100 & 37 & 23 & 100 & 10.83 & 0.306 & 100 \\
\hline S. vermicularis & 7 & 344 & 83 & 110 & 786 & 100 & 103.92 & 2.94 & 92 \\
\hline S. rudolphii & 105 & 36 & 100 & 94 & 8 & 100 & 20.25 & 0.573 & 100 \\
\hline T. lapidaria & 52 & 22 & 100 & 44 & 43 & 100 & 13.42 & 0.38 & 100 \\
\hline Tharyx marionii & 2 & 10 & 50 & 4 & 1 & 50 & 1.42 & 0.04 & 50 \\
\hline V. infundibulum & 66 & 141 & 100 & 85 & 34 & 100 & 27.17 & 0.769 & 100 \\
\hline Modiolus barbatus & 6 & 9 & 66 & & 6 & 33 & 1.75 & 0.05 & 50 \\
\hline Cyclops sp. & 2 & 4 & 50 & 2 & 1 & 50 & 0.75 & 0.021 & 50 \\
\hline L. savignyi & 4213 & 2485 & 100 & 3730 & 2221 & 100 & 1054.1 & 29.82 & 100 \\
\hline Tanais cavolinii & 7 & 2 & 66 & 6 & 52 & 66 & 5.58 & 0.158 & 67 \\
\hline E. rapax & 177 & 2667 & 100 & 548 & 670 & 100 & 338.5 & 9.576 & 100 \\
\hline E.brasiliensis & 7 & 4351 & 100 & 38 & 6 & 83 & 366.83 & 10.38 & 92 \\
\hline P. marmoratus & 40 & 19 & 83 & 26 & 20 & 100 & 8.75 & 0.248 & 92 \\
\hline P. longicornis & 13 & 19 & 83 & 8 & 8 & 100 & 4 & 0.113 & 92 \\
\hline B. perforatus & 1 & 1 & 33 & 6 & 23 & 83 & 2.58 & 0.073 & 58 \\
\hline Bowerbankia sp. & $*$ & $*$ & 83 & $*$ & $*$ & 83 & $*$ & $*$ & 67 \\
\hline C. lepadiformis & 648 & & 50 & 1388 & & 50 & 186.33 & 5.271 & 50 \\
\hline P. microcosmus & 1 & 7 & 50 & 2 & 5 & 83 & 1.25 & 0.035 & 67 \\
\hline S. partita & 234 & 50 & 100 & 136 & 610 & 100 & 85.83 & 2.428 & 100 \\
\hline S. plicata & 16 & & 50 & 2 & 23 & 66 & 3.33 & 0.094 & 58 \\
\hline
\end{tabular}

Western Mediterranean Sea. The only exception seems to be the cases of assemblages affected by thermal pollution, where the prevailing taxa are Mollusca followed by Polychaeta and Crustacea (Bellan-Santini et al., 1976). For these reasons, the majority of the relevant information focuses on polychaetes and crustaceans.

Reviewing the contemporary bibliography, we can consider the species $S$. rudolphii, Platynereis dumerilii, $H$. norvegica, Leptochelia savingnyi, C. intestinalis, Nebalia sp., S. partita, Balanus trigonus and Bugula stolonifera as common components of the assemblages of polluted ports in the Mediterranean (Pérès and Picard, 1964; Bellan-Santini, 1968; Bellan-Santini et al., 1976; Bellan, 1980; Bitar, 1982; Desrosiers et al., 1986; Baxevanis and Chintiroglou, 2000, and others). The rest of the species found in our research was among the commonly recorded from the different facies of the assemblage of photophilic algae.

After a close examination of the faunistic components of the three examined stations, we can classify them according to Pérès and Picard (1964) and Bellan-Santini et al. (1994). The dominant species at st 1 and st 2 were the ascidians $C$. intestinalis, C. lepatiformis, S. partita, the amphipods $E$. rapax, $C$. acutum, E. brasiliensis, the polychaetes $S$. rudolphii, H. norvegica, O. pallidus and the green algae Ulva rigida. So both assemblages can be placed among the hard substrate assemblages of polluted ports. In st3, the situation is a little more complicated, since it corresponds to the assemblages of photophilic algae as well as those of semipolluted ports. The presence of the sea anemone A. pelluci$d u s$, the great numbers of Syllidae polychaetes (9) and the 
Table 3

Mean numerical abundance $(\mathrm{mA})$, frequency $(F)$ and mean dominance $(\mathrm{mD})$ values from the fishery port of N. Mihaniona (st3)

\begin{tabular}{|c|c|c|c|c|c|c|c|c|c|}
\hline Taxa & st3 w94 & st3 s94 & $F(\%)$ & st3 w95 & st3 s95 & $F(\%)$ & $\mathrm{mA}$ & $\mathrm{mD}$ & $F(\%)$ \\
\hline Eudendrium sp. & $*$ & $*$ & 100 & $*$ & $*$ & 83 & $*$ & 0 & 92 \\
\hline A.pellucidus & 1538 & 3455 & 100 & 2043 & 1112 & 100 & 679 & 29.83 & 100 \\
\hline Leptoplana sp. & 7 & 21 & 66 & 17 & 19 & 100 & 5.33 & 0.234 & 82 \\
\hline Stylochus sp. & & 12 & 50 & 2 & 14 & 83 & 2.33 & 0.102 & 67 \\
\hline Turbellaria sp.1 & 4 & & 16 & 3 & 32 & 100 & 3.25 & 0.143 & 58 \\
\hline Nematoda & 54 & 92 & 83 & 117 & 82 & 100 & 28.75 & 1.263 & 92 \\
\hline Oligochaeta & 45 & 2 & 66 & 16 & 26 & 83 & 7.42 & 0.326 & 75 \\
\hline D. concharum & 4 & 11 & 100 & 42 & & 50 & 4.75 & 0.209 & 75 \\
\hline E. gemmifera & 322 & 1245 & 100 & 503 & 483 & 100 & 212.8 & 9.348 & 100 \\
\hline Glycera sp. & & & & & 2 & 33 & 0.17 & 0.007 & 17 \\
\hline Grubeosyllis sp. & 3 & 9 & 50 & 3 & 8 & 66 & 1.92 & 0.084 & 58 \\
\hline H. bioculatus & 17 & 28 & 100 & 73 & 16 & 100 & 11.17 & 0.491 & 100 \\
\hline H. filiformis & 4 & 7 & 50 & 16 & 10 & 66 & 3.08 & 0.135 & 58 \\
\hline H. norvegica & 6 & 18 & 50 & 186 & 87 & 100 & 24.75 & 1.087 & 75 \\
\hline Kefersteinia cirrata & 2 & & 16 & 6 & 5 & 83 & 1.08 & 0.047 & 50 \\
\hline Lumbrinereis gracilis & 10 & 23 & 100 & 15 & 19 & 100 & 5.58 & 0.245 & 100 \\
\hline M. perarmata & 11 & 3 & 100 & 10 & 17 & 66 & 3.42 & 0.15 & 83 \\
\hline P. madeirensis & 4 & 1 & 33 & 11 & 3 & 66 & 1.58 & 0.069 & 50 \\
\hline P. caeca & 7 & 9 & 100 & 26 & 4 & 100 & 1.67 & 0.073 & 100 \\
\hline Polydora hoplura & 3 & 8 & 50 & 31 & 12 & 100 & 4.5 & 0.198 & 75 \\
\hline Potamilla reniformis & 2 & 3 & 33 & 6 & 2 & 66 & 1.08 & 0.047 & 50 \\
\hline P. steenstrupi & & 12 & 50 & 6 & 11 & 50 & 2.42 & 0.106 & 50 \\
\hline S. spinulosa & 1 & 8 & 50 & 7 & 5 & 66 & 1.75 & 0.077 & 58 \\
\hline S. funchalensis & 1083 & 336 & 100 & 769 & 481 & 100 & 222.4 & 9.772 & 100 \\
\hline S. vermicularis & 15 & 26 & 83 & 84 & 196 & 100 & 26.75 & 1.175 & 92 \\
\hline Syllis hyalina & 5 & 9 & 100 & 9 & 6 & 66 & 2.42 & 0.106 & 83 \\
\hline Mytillus galloprovincialis & 22 & 41 & 83 & 12 & 3 & 83 & 6.5 & 0.286 & 83 \\
\hline Phoxichilidiidae & 38 & 18 & 100 & 9 & 8 & 83 & 6.08 & 0.267 & 92 \\
\hline C. tuberculata & 42 & 16 & 100 & 22 & 6 & 100 & 7.17 & 0.315 & 100 \\
\hline Corophium acherusicum & 15 & 8 & 100 & & & & 1.92 & 0.084 & 50 \\
\hline C. acutum & 623 & 754 & 100 & 399 & 2597 & 100 & 364.4 & 16.01 & 100 \\
\hline C. sextonae & 321 & 978 & 100 & 12 & 41 & 100 & 112.7 & 4.95 & 100 \\
\hline E. rapax & 274 & 709 & 100 & 91 & 420 & 100 & 124.5 & 5.47 & 100 \\
\hline E. brasiliensis & 240 & 178 & 100 & 1 & 36 & 50 & 37.92 & 1.666 & 75 \\
\hline Stenothoe cavimana & 24 & & 50 & 35 & & 50 & 4.92 & 0.216 & 50 \\
\hline P. longicornis & 4 & 14 & 83 & & 2 & 16 & 1.67 & 0.073 & 50 \\
\hline B. eburneus & 199 & 353 & 100 & 111 & 123 & 100 & 65.5 & 2.878 & 100 \\
\hline Phallusia fumigata & 3 & 9 & 83 & 7 & 12 & 100 & 2.58 & 0.113 & 92 \\
\hline S. partita & & 3 & 50 & 8 & 14 & 66 & 2.08 & 0.091 & 58 \\
\hline S. plicata & & 2 & 16 & 8 & 7 & 66 & 1.42 & 0.062 & 42 \\
\hline
\end{tabular}

increasing flora diversity (for example, Bryopsis pennata, Ceramium fastigiatum, Cladophora prolifera, Dictyota dichotoma, Lomentaria articulata), possibly shows that it represents an intermediate phase between the two aforementioned assemblages.
We can conclude that the fauna of the artificial hard substrates in ports is composed by a complex of species from the photophilic algae assemblage, which are resistant to a variety of pollution sources, always in dependence with their different biotic interactions in space and time. According to

Table 4

Number of species classified among the three categories according to their frequency and total number of species per station per year

\begin{tabular}{|c|c|c|c|c|c|c|}
\hline & st1 1994 & st1 1995 & st2 1994 & st2 1995 & st3 1994 & st3 1995 \\
\hline Characteristic & 41 & 44 & 46 & 46 & 44 & 52 \\
\hline Common & 12 & 14 & 11 & 6 & 19 & 13 \\
\hline Rare & 8 & 8 & 13 & 11 & 28 & 22 \\
\hline Total & 61 & 66 & 70 & 63 & 91 & 87 \\
\hline
\end{tabular}


Table 5

Numerical abundance, species richness, Shannon-Weaver and Evenness calculations per sampling station

\begin{tabular}{|c|c|c|c|c|}
\hline Sampling station & Numerical abundance & Species richness & Shannon-Weaver $\left(H^{\prime}\right)$ & Evenness $\left(J^{\prime}\right)$ \\
\hline St1 & 15643 & 71 & & \\
\hline Winter 1994 & 2291 & 45 & 3.117 & 0.574 \\
\hline Summer 1994 & 6811 & 55 & 3.684 & 0.631 \\
\hline Winter 1995 & 2064 & 51 & 3.848 & 0.678 \\
\hline Summer 1995 & 4477 & 59 & 3.714 & 0.631 \\
\hline St2 & 42294 & 75 & & \\
\hline Summer 1994 & 15213 & 60 & 2.794 & 0.483 \\
\hline Winter 1995 & 7314 & 54 & 2.652 & 0.457 \\
\hline Summer 1995 & 13364 & 55 & 2.503 & 0.437 \\
\hline St3 & 26297 & 105 & & \\
\hline Winter 1994 & 5872 & 68 & 3.389 & 0.561 \\
\hline Summer 1994 & 9461 & 73 & 3.298 & 0.534 \\
\hline Winter 1995 & 5100 & 77 & 3.263 & 0.524 \\
\hline Total & 84234 & 125 & & \\
\hline
\end{tabular}

Bellan-Santini (1968), three stocks of species are representative, the first includes species from the photophilic algae assemblage, the second species-indicators of pollution and the third species that are widely distributed and they appear to port assemblages. The species of the above groups differentiate in a geographical scale. It should be added here that the classification of the Polychaetofauna in a broader sea region could be distinguished in 11 stocks of species (Bellan, 1980). Some of the species that belong to these stocks seem to be included in this study too. H. norvegica, for example, showed a gradual decrease in abundance from station 1 (heavily polluted site) towards station 3 (lightly affected area). On the other hand, the species $S$. rudolphii, which is typical in polluted areas, did not occur at station 3, though its abundance increased gradually from station 2 towards station 1. Another species with similar interest is $O$. pallidus, for which there is not much evidence about its occurrence in hard substrata (that contain confined sediment) or about its relationship with pollution. All of the three aforementioned species can be included in the stock of pollution indicators (see Bellan, 1980). Another stock of species that are sensitive to increasing pollution includes the species of the genus Syllis and the species S. funchalensis (common in photophilic algae and Maerl assemblages) (see Bellan, 1964).

\subsection{Diversity, abundance and similarity}

Overall 84234 individuals were counted, belonging to 125 species. The distribution of individuals and species per sampling station and, also, the results from Shannon-Weaver $\left(H^{\prime}\right)$ and Evenness $\left(J^{\prime}\right)$ calculations are presented in Table 5. Obviously the lowest values for both indices appear at st2. Many authors mention that $H^{\prime}$ values are representative for the 'healthiness' of an assemblage. The stability of $H^{\prime}$ and $J$ ' at each station through time, indicates that the above assemblages are long-standing, well aged and fitted to the local conditions. The index depends on two factors: the number of species and their abundance. That's why the local extinction of species by pollution may be masked by little or no change in the value of $H^{\prime}$, so these indices must be crosschecked with other features of the assemblages. When the numerical abundance and the species' richness modifies analogically, the index gains high values. This is the case for st1. The numerical abundance is lower than at the other stations but the same thing applies for species' richness. As a result, the index gains values similar to st3, despite the fact that the number of species at the latter is much greater (so does the numerical abundance). The numerical abundance at st 2 was high but the number of species was low. Consequently, $H$ values were low. At that point, we should state that numerical abundance values fall during wintertime. This fact is quite common and must be related to some biological interactions, mainly the reproductive strategies of the faunistic components.

The results of cluster and MDS analysis are depicted in Fig. 2 The stress value for the two-dimensional MDS plot was 0.03 , indicating a proper group separation. The results of Anosim $(R=0.944$, significance level is $0.2 \%)$ indicate discrimination between the groups of samples. Therefore, the cluster and the MDS analysis are confirmed.

From these figures, we observe three main groups at a $60 \%$ similarity level. Each group was composed by the samples from each station. By looking closer to the first group matching all the samples from the port of Thessaloniki, we can detect a clear separation of the sample from winter 1994. This sample relates to that of winter 1995, while the summer samples from both years are classified together at the same similarity degree. At the second group including samples from Kalamaria harbor, the pattern is undoubtedly seasonal. Summer samples are classified together. Winter samples follow the same rule in an even higher similarity degree. At the third group counting samples from N. Michaniona port, the pattern is rather annual than seasonal. Two subgroups are detectable, the one containing all the samples from 1994, while the other from 1995. We can also notice that the likeness is higher during 1995. 


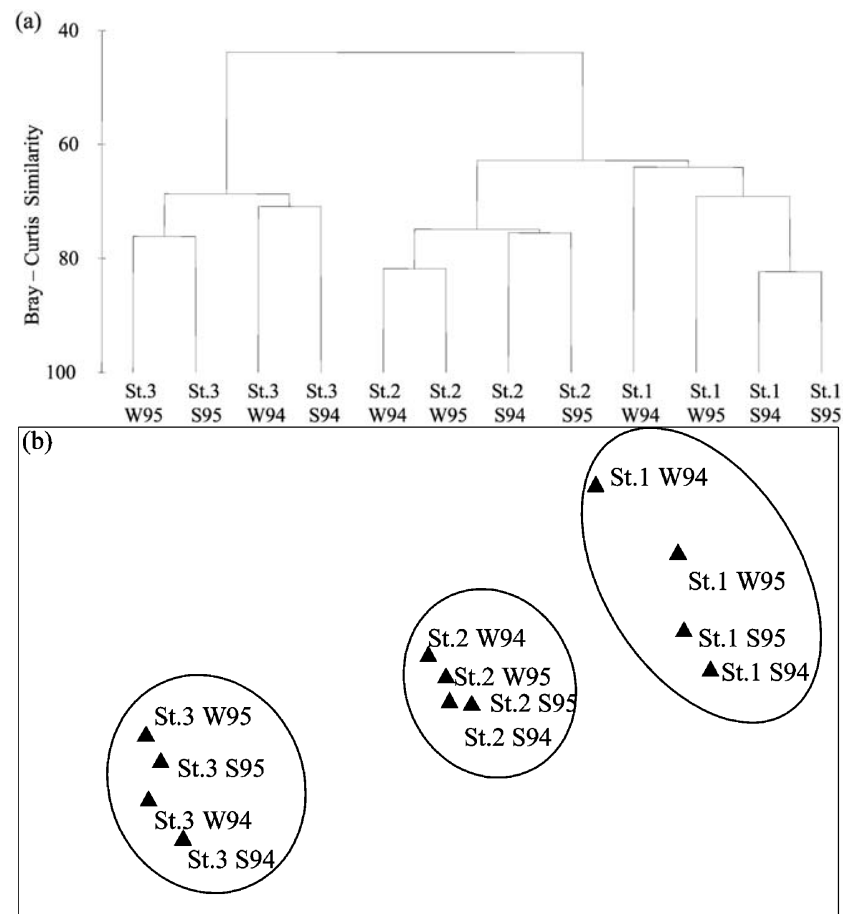

Fig. 2. Results of (a) cluster analysis and (b) MDS based on Bray-Curtis similarity index, during 2 years of survey.

From the above it is evident, in terms of species composition, that st 3 differentiates from the others. The loss of the seasonal pattern at st3 may indicate some kind of disturbance. Indeed a new dock was constructed during the first months of 1995. This construction acts as an obstacle to water movement. The currents are altered and so does the sedimentation rate. This fact is reflected in our results. It seems to lead to an impoverishment of the assemblage that naturally occurs.

\section{Results using the taxa of Polychaeta}

Polychaetes are among the most frequent and abundant marine benthic organisms in man-made harbors (Fauchald and Jumars, 1979; Barnard and Reish, 1959) and are also among the most 'species-rich' groups. There are many authors who suggest that they can play a key role to biomonitoring studies (Reish, 1978; Bellan, 1980; Wenner, 1988; Warwick, 1993). We attempt to test this hypothesis in our data using their numerical abundance, on the one hand based on species composition and on the other hand on their feeding guilds to perform a similarity analysis. Polychaetes' feeding guilds are fairly known (Fauchald and Jumars, 1979). When an environmental disturbance occurs, a particular trophic group will dominate, depending on the type of disturbance (Desrosiers et al., 1986). Consequently we can use their trophic relation, which is a clearly functional characteristic, for the purposes of environmental impact studies.

The results of the cluster and MDS analysis for both cases are presented in Fig. 3. The stress value for the twodimensional MDS plot was 0.04 (c) and 0.05 (d), indicating a
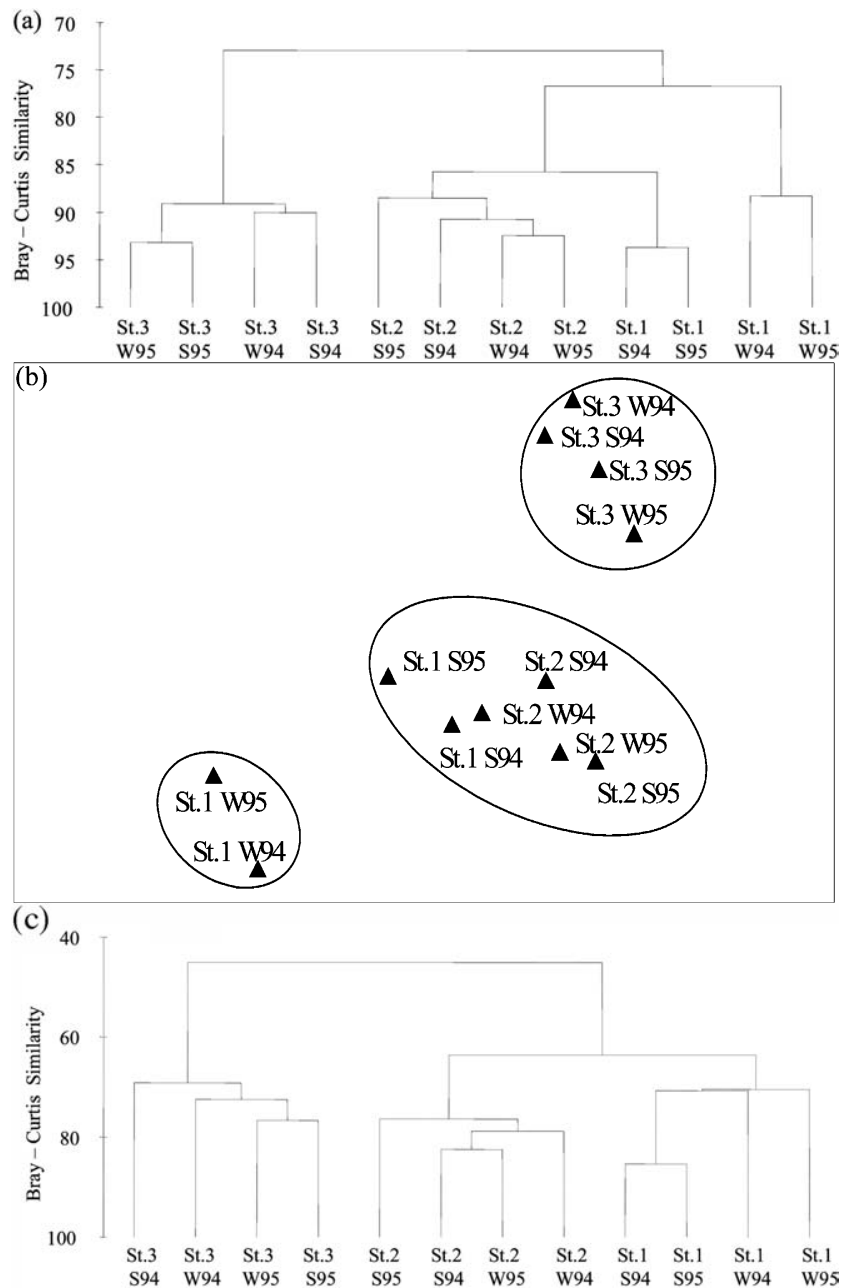

(d)
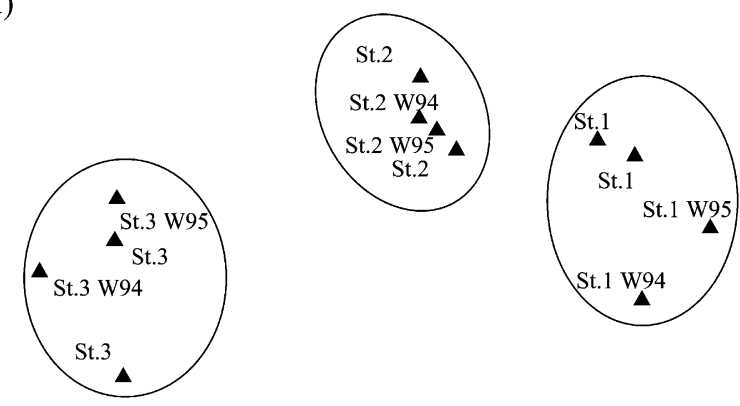

Fig. 3. Cluster and MDS analysis based on the numerical abundance of the feeding guilds of polychaetes (a and c) and on the numerical abundance of polychaetes species (b and d), based on Bray-Curties similarity index.

very good group separation in both cases. The results of Anosim $(R=0.896$ significance level is $0.2 \%$ for the feeding guilds case and $R=0.910$ significance level is $0.2 \%$ for the species composition) indicate discrimination between the groups of samples, confirming the cluster and the MDS analysis.

We can easily perceive that the configurations produced are very similar in both cases. Indeed all samples from each station are clustered together. We must comment the fact that the similarity is extremely high in the case of feeding guilds 
and this changes the image a little. If we compare Fig. 2 with Fig. 3. we find no differences among the dendrogrammes and the MDSs constructed from numerical abundances per species composition data. But we do find minor differences in the case of feeding guilds where we can detect once again three major groups in $85 \%$ similarity level. The first one contains the winter samples from the port of Thessaloniki, the second all the samples from Kalamaria plus the summer samples from Thessaloniki and the third all the samples from N. Michaniona. This 'change of place' of summer samples from the port of Thessaloniki may be attributed to the environmental conditions during the summer months, especially to the low hydro-dynamism. The high temperatures and the limited water renewal occur in summer, so the profile of st 1 is very closely linked to st 2 , a fact that is reflected in our data by a change through the feeding guilds of polychaetes in favor of filter-feeders. We can also mark an increase of the carnivores' percentage, mainly caused by the species $O$. pallidus. This species duplicates its numerical abundance during summer months, probably due to a successive reproductive period, but also to the fact that this species is capable of feeding on diatoms, bacteria and detritus, acting as a deposit-feeder (Fauchald and Jumars, 1979) and consequently favored by the environmental conditions during the hot season. A closer examination of the second group reveals three subgroups including (1) the summer samples from the port of Thessaloniki, (2) one summer sample from Kalamaria and (3) the rest of the samples from Kalamaria. The seasonal pattern is kept in all three cases in st1 (port of Thessaloniki), though a little altered in st2 (Kalamaria harbor) (when we used the feeding guilds data), and completely lost in st3 (N. Michaniona) where it is replaced by an annual pattern. Therefore, we can conclude that the taxa of polychaeta can be acceptably used for the description of the general terms of these three assemblages producing the same groups, even when we consider them as one functional group.

\section{Conclusion}

The facts that were recorded during this study led to conclusions which have been more or less reported by many researchers (Bellan, 1980; Wenner, 1988; Bellan-Santini et al., 1994; Baxevanis and Chintiroglou, 2000; Damianidis and Chintiroglou, 2000 and others): (a) there is no adequate information on the structure and function of the benthic assemblages on hard substratum in ports, (b) the qualitative composition of these assemblages is significantly even, as far as the pollution indicators are concerned, (c) the differentiations that were observed, at both qualitative and quantitative levels, should be attributed to different constructional background, to human intervention (e.g. extension of ports) and, also, to the different operational activities (e.g. tourism, commercial docks etc.) at each port and, finally, (d) the biotic interactions between the living organisms (e.g. space competition, feeding adaptations and habits etc.) play a significant role for these differentiations.

\section{Acknowledgements}

We are very grateful to the Hellenic General Secretariat of Research and Technology who financed this study, supporting our efforts and to Dr. D. Bellan-Santini and Dr. G. Bellan for their invaluable advice and contribution to the improvement of the study.

\section{References}

Bakus, J.G., 1990. Quantitative Ecology and Marine Biology. G.A. Balkenna,, Rotterdam, pp. 157.

Barnard, J.L., Reish, D.J., 1959. Ecology of Amphipoda and Polychaeta of Neewport Bay, Caliphornia. Occasional Papers, 21. Allan Hancock Foundation, pp. 1-103.

Baxevanis, A., Chintiroglou, C., 2000. Peracarida crustacean of the artificial hard-substratum in N. Mihaniona (N. Aegean). Belg. J. Zool. 130 (Suppl), 11-16.

Bellan, G., 1964. Contribution à l'étude systématique bionomique et écologique des Annelides Polychaetes de la Méditerranée. Thèse. Université Aix-Marseille, pp. 371.

Bellan, G., 1980. Relationship of pollution to rocky substratum polychaetes on the French Mediterranean coast. Mar. Pollut. Bull. 11, 318-321.

Bellan, G., Pérès, J.M., 1994. La pollution des Mers. Presses Universitaires de France, pp. 127.

Bellan-Santini, D., 1968. Contribution à l'étude des milieux portuaires (Le Vieux Port de Marseille). Rapp. Comm. Int. Mer Médit. 19 (2), 93-95.

Bellan-Santini, D., Desrosiers, G., Bréthes, J.C., 1976. Action du rejet thermique de l'usine de Martigues-Ponteau sur les peuplements de substrats durs à dominance de zoobenthos dans la partie supérieure de l'étage infralittoral. Tethys 8 (1), 83-92.

Bellan-Santini, D., 1981. Influence des pollutions sur le peuplement des amphipodes dans la biocénose des algues photophiles. Tethys 10 (2), 185-194.

Bellan-Santini, D., Lacaze, J.-C., Poizat, C., 1994. Les biocénoses marines et littorales de Méditerranée, synthèse, menaces et perspectives. Muséum National d'Histoire Naturelle, Paris, pp. 246.

Bitar, G., 1982. Influence d'un grand émissaire urbain sur la distribution du zoobenthos de substrat dur dans la région de Marseille (Méditerranée Nord-Occidental). Tethys 10 (3), 200-210.

Chintiroglou, C., Koukouras, A., 1992. A population of the sea anemone Anemonia viridis (Forskal, 1775) and its associated flora and fauna in the North Aegean Sea. Int. Revue ges. Hydrobiol. 77 (3), 483-495.

Clarke, K.R., Warwick, R.M., 1994. Change in marine communities: an approach to statistical analysis and interpretation. Nat. Environ. Res. Council, UK.

Damianidis, P., Chintiroglou, C., 2000. Structure and function of Polychaetofauna living in Mytilus galloprovincialis assemblages in Thermaikos Gulf (north Aegean Sea). Oceanol. Acta 23 (3), 323-339.

Desrosiers, G., Bellan-Santini, D., Brethes, J.-C., 1986. Organisation trophique de quatre peuplements de substrats rocheux selon un gradient de pollution industrielle (Golfe de Fos, France). Mar. Biol. 9, 107-120.

Fauchald, K., Jumars, P.A., 1979. The diet of worms: a study of polychaetes feeding guilds. Oceanogr. Mar. Biol. Ann. Rev. 17, 193-284.

Gaston, K., Spicer, J.I., 1996. Biodiversity. An Introduction. Blackwell Science, pp. 111

Gray, J., Mirza, F., 1979. A possible method for the detection of pollutioninduced disturbance on marine benthic communities. Mar. Pollut. Bull. $10,142-146$.

Guille, A., 1970. Bionomie benthique du plateau continental de la cote catalane francaise. II Les communautes de la macrofaune. Vie Milieu 21, 149-280.

Hargrave, B.T., Thiel, H., 1983. Assessment of pollution induced changes in benthic community structure. Mar. Pollut. Bull. 14 (2), 41-46. 
Kaandorp, J.A., 1986. Rocky substrate communities of the infralittoral fringe of the Boulonnais coast, NW France: a quantitative survey. Mar. Biol. 92, 255-265.

Kamba, E., Artemiadou, V., Lazaridou-Dimitriadou, M., 2000. Ecological quality of the river Axios (N. Greece) during spring and summer 1997. Belg. J. Zool. 130 (Suppl), 23-30.

Krestenitis, J., Christopoulos, S., Valioulis, H., Hyder, P., 1997. The study of the region of fresh water influence of Thermaikos Gulf. Proc. 5th Hel. Symp. Oceanogr. Fish. 1, 47-49.

Pérès, J.M., Picard, J., 1964. Nouveau manuel de la bionomie benthique de la mer Méditerranée. Rec. Trav. Stat. Mar. Endoume 31 (47), 1-137.

Reish, D.J., 1978. The effects of heavy metals on Polychaetous annelids. Rev. Int. Oceanogr. Med. 49, 99-104.
Stirn, J., 1981. Manual of methods in aquatic environment research. Part 8. Ecological assessment of pollution effects (Guidelines for the F.A.O. (GFCM)/UNEP Joint Coordinated Project on Pollution in Mediterranean). F.A.O. Fisheries Technical Paper, 209, pp. 1-190.

Tack Kit, D., 1976. Étude de la faune de substrat rocheux dans la zone de rejet des eaux résiduaires de la ville de Marseille (France). Tethys 7 , 191-212.

Warwick, R.M., 1993. Environmental impact studies on marine communities: pragmatical considerations. Aust. J. Ecol. 18, 63-80.

Weinberg, S., 1978. The minimal area problem in invertebrate communities of Mediterranean rocky substrate. Mar. Biol. 49, 33-40.

Wenner, A.M., 1988. Crustacean and other invertebrates as indicators of beach pollution. In: Soule, D.F., Kleppel, G.S. (Eds.), Marine Organisms as Indicators. Springer, Berlin, pp. 199-229. 